\title{
Transcriptome comparisons detect new genes associated with apoptosis of cattle and buffaloes preantral follicles
}

\author{
Khairy Mohamed Zoheir ${ }^{* *}$ (D), Ahmed Mohamed Darwish', Yang Liguo² and Abdelkader E. Ashour ${ }^{3}$
}

\begin{abstract}
Background: To develop new breeding technology to improve the breeding ability of bovine, it is the development trend to find the main reason for the occurrence of atresia in these organisms. Transcriptomes of small (100-120 $\mu \mathrm{m})$ and large $(200-220 \mu \mathrm{m})$ preantral follicles from cattle and buffalo ovaries were evaluated in vivo and in vitro to understand the transcriptional modulation in preantral follicles that leads to the phenomenon of atresia.

Methods: The preantral follicles were checked as dead, damage, or live follicles in vivo and in vitro by using trypan blue then bisbenzimide and propidium iodine. Transcriptomes of small (100-120 $\mu \mathrm{m})$ and large $(200-220 \mu \mathrm{m})$ preantral follicles of cattle and buffalo were evaluated in vivo and in vitro by microarray and RT-PCR. Healthy preantral follicles were selected based on staining results, and then RNA was extracted from them.

Results: The viability percentage of preantral follicles in cattle was higher (26.7\% and 20\%) than buffalo (10\%) in vivo and in vitro, respectively. According to the microarray data analysis for cattle preantral follicles, only eleven genes were detected corresponding to five upregulated and six downregulated in large size (200-220 $\mu \mathrm{m})$ compared to small $(100-120 \mu \mathrm{m})$ size preantral follicles, while in buffalo, 171 genes were detected (92 upregulated and 79 downregulated) in large size compared to small preantral follicle size. The results of RT-PCR of the selected genes (FASTKD1, BAG2, RHOB, AGTR2, MEF2C, BCL10, G2E3, TM2D1, IGF-I, IGFBP3, PRDX3, and TRIAP1) validated the microarray results. In conclusion, the data of gene expression showed significant differences between small and large sizes in both buffalo and cattle preantral follicles.

Conclusion: Apoptotic genes were upregulated in the large preantral follicle compared with the small preantral follicles. Moreover, the expression level of these apoptotic genes was significantly upregulated in buffalo than in the cattle. Most of these genes were significantly upregulated in the large buffalo preantral follicle compared with the small size. However, anti-apoptotic genes were upregulated in large cattle preantral follicle and downregulated in large buffalo preantral follicle.
\end{abstract}

Keywords: Atresia, Preantral follicles, Gene expression, Apoptosis, Cattle, Buffalo

\footnotetext{
* Correspondence: khma25@gmail.com

${ }^{1}$ Cell Biology Department, National Research Centre, Dokki 12622, Egypt

Full list of author information is available at the end of the article
}

\section{Springer Open}

(c) The Author(s). 2021 Open Access This article is licensed under a Creative Commons Attribution 4.0 International License, which permits use, sharing, adaptation, distribution and reproduction in any medium or format, as long as you give appropriate credit to the original author(s) and the source, provide a link to the Creative Commons licence, and indicate if changes were made. The images or other third party material in this article are included in the article's Creative Commons licence, unless indicated otherwise in a credit line to the material. If material is not included in the article's Creative Commons licence and your intended use is not permitted by statutory regulation or exceeds the permitted use, you will need to obtain permission directly from the copyright holder. To view a copy of this licence, visit http://creativecommons.org/licenses/by/4.0/. 


\section{Background}

Buffalo and cattle receive more attention than the other livestock species despite their importance as a potential source of meat and milk, particularly in developing countries.

The oocyte quality is the direct and most important factor for fertilization to develop an animal. Therefore, it is meaningful to explore the mechanisms of flucogenesis and oogenesis quality trait formation. Follicle and oocyte quality is one of the major challenges which the buffalo industry faces. Buffalo has fewer primordial follicles than bovine species (10,000-19,000 vs 150,000), smaller antral follicles, and a higher prevalence of atresia (82-92\%) ([1]). The number of viable follicles and oocytes in newborn calves' ovaries is ranging from 10,000 to 350,000 at birth, and in 12-month-old heifers, from 1920 to 40,960 ([2]). The neonatal bovine ovary contains many primordial follicles, but only about 0.1 percent of these follicles will mature and ovulate during a cow's reproductive development ([3]). Most follicles in the mammalian ovary die of atresia, and only a small number of follicles are selected for ovulation. Although follicle atresia happens during female reproductive life, the exact mechanism behind their extensive large cell death is indefinite. Several investigations suggested that follicle atresia is related to DNA fragmentation of the cell, an important biochemical marker of apoptosis [4]. Apoptosis has morphologic and biochemical characteristics and it is one of the types of programmed cell death [5]. The apoptotic events were induced by several signaling pathways [6]. One of the most important apoptotic pathways is the mitochondriadependent pathway. Cytochrome $\mathrm{c}$ is speedily released from the mitochondria into the cytosol after exposing the cells to apoptotic stimuli [7]. Several genes, such as protein 53 (p53) [8], Bcl-2-associated X protein (Bax) [9], and B cell lymphoma 2 (Bcl-2) [7], are associated with the release of cytochrome c, either positively or negatively. The Liberation of Cytochrome $\mathrm{c}$ activates the cell death protease and caspase- 3 release and thus can be fatal for cells [10].

Key post-transcriptional regulators like Fas-activated serine/threonine kinase (FASTK) family proteins appeared as mitochondrial gene expression and have altered function in the regulation of mitochondrial RNA [11]. G2/M phase-specific E3 (G2E3) extremely regulated at both levels of transcription and post-translation, plays an important role in early embryonic development and becomes downregulated in response to DNA damage, as murine G2E3-deficient blastula suffers massive apoptosis [12]. Ras Homolog Family Member B (RhoB) gene regulates many cellular processes such as gene transcription and cell cycle progression [13]. Insulin-like growth factors (IGFs) regulate follicular development and granulosa cell apoptosis and thus can block apoptosis enhanced by dexamethasone in many cell types (Armstrong et al. 2001).

To investigate the difference in apoptosis and its relationship with atresia between small and large healthy preantral follicles in both buffalo and cattle, we used a more ultimate procedure to determine changes in gene expression using the microarray assay. This investigation was designed to study the association of cell death program genes with preantral follicle apoptosis.

\section{Methods \\ Chemicals}

All the chemicals and antibiotics used in this study were purchased from Sigma-Aldrich Company, Ltd., Germany.

\section{Animals}

We used ovaries from both buffalo and cattle slaughtered at an Islamic slaughterhouse in Wuhan, China. We removed all ovaries from the animals within a few minutes after slaughter.

\section{Isolation of preantral follicles}

Twenty ovaries were collected from both buffalo (Bubalus bubalis) and cattle (Bos taurus), and then were placed in 10 bags and were kept in saline solution $(0.9 \%$ $\mathrm{NaCl}$ ) with penicillin (200 IU/mL) and streptomycin $(200 \mu \mathrm{g} / \mathrm{mL})$ at $30-35^{\circ} \mathrm{C}$.

According to Khairy et al. [14], we isolated different size of both buffalo and cattle preantral follicles as follows: sections of the ovarian cortex were excised by scalpel and placed into a tissue chopper adjusted to produce $500 \mu \mathrm{m}$ sections. These small to minute segments were placed in Dulbecco's phosphate-buffered solution supplemented with $36 \mu \mathrm{g} \mathrm{mL}^{-1}$ sodium pyruvate, $1 \mu \mathrm{g} \mathrm{mL} \mathrm{m}^{-1}$ glucose, and $3 \mathrm{mg} \mathrm{mL}^{-1} \mathrm{BSA}$. To remove all large fragments and debris, samples were filtered by a $500-\mu \mathrm{m}$ filter and washed several times, then filtered by a $38-\mu \mathrm{m}$ filter to exclude blood cells and other fine particles. The cells on the $38-\mu \mathrm{m}$ filter were washed and collected in an embryo searching dish $(100 \times 20 \mathrm{~mm}$, Falcon $)$.

\section{In vivo experiment}

The freshly isolated follicles were examined under an inverted microscope; the morphologically normal follicles were selected (healthy appearing, spherical with one or more compact layers of granulosa cells around the oocyte with an intact basal membrane, with no apparent sign of necrosis and no antrum).

Under an inverted microscope, two different sizes small $(100-120 \mu \mathrm{m})$ and large $(200-220 \mu \mathrm{m})$ of fresh healthy preantral follicles $(n=100)$ from cattle and buffalo were selected. 


\section{In vitro experiment}

Only healthy preantral follicles $(80-100 \mu \mathrm{m})$ were selected and cultured individually in droplets $(n=100)$ of TCM-199 $(20 \mu \mathrm{L})$ plus Follicle Stimulating Hormone (FSH) $(100 \mathrm{ng} / \mathrm{mL})$ and EGF $(100 \mathrm{ng} / \mathrm{mL})+$ epidermal growth factor (EGF) (100 $\left.\mathrm{ng} \mathrm{mL}^{-1}\right)$. Then, it was supplemented with 10\% NCS (Newborn Calf Serum, Gibco), $0.23 \mathrm{mM}$ sodium pyruvate, $75 \mathrm{mg} / \mathrm{ml}$ of streptomycin, $100 \mathrm{mIU} / \mathrm{ml}$ of penicillin, 1\% ITS (Insulin Transferring Selenium; Gibco), and $2.2 \mathrm{~g} / \mathrm{L}$ sodium bicarbonate covered sterile mineral oil in falcon culture dishes at $38.5^{\circ} \mathrm{C}, 100 \%$ humidity, and $5 \% \mathrm{CO}_{2}$ for up to 25 days. To avoid contamination, the medium was changed with fresh medium every 3 days. At the end of the in vitro experiment, the diameter of follicles was measured by a camera of inverted microscope supported by diameter in its lenses, and then selected the following two sizes of follicles: $100-120$ and 200-220 $\mu \mathrm{m}$ [14].

\section{Viability screening}

To monitor the morphological deformity or degeneration, half of the preantral follicles from both in vivo and in vitro experiments were stained with Trypan blue to categorize their viability on the basis of the degree of dye exclusion. Unstained follicles were classified as viable and fully stained follicles as dead. Follicles with medium staining were regarded as damaged. And the rest of the preantral follicles were double-stained by bisbenzimide ( $\mathrm{H}$ 33342) plus propidium iodine and compared with fresh controls to examine the morphological aspects such as the presence of an intact follicle membrane, a flattened or cuboidal granulosa cell layer, and presence of a nucleus. Double staining helped us to analyze the proportions of live and dead granulosa cells and also the nuclear components.

\section{Total RNA extraction from preantral follicles}

Only healthy buffalo/cattle preantral follicles (100-150 preantral follicles) from every size were suspended and collected by low-speed centrifugation (triple samples for every size); then we added $300 \mu$ lysis/binding buffer shake or repeatedly beat, so that the cells are lysed.

We used an isolation kit which was purchased from Applied Biosystem AM1556 to extract the total RNA. The concentration and quality of RNA were measured by Nanodrop (Thermo). Three replicates of each RNA sample for every size were processed for hybridization to Bovine Affymetrix Genome Array. Other parts of the same RNA samples were used for qPCR analysis for some genes to confirm microarray data.

\section{Microarray analysis}

According to the manufacturer's standard protocols, RNA of small and large preantral follicles samples were labeled, hybridized, and scanned. The obtained raw data from array images analysis by Affymetrix GeneChip Command Console (version 4.0, Affymetrix) was analyzed by Genesrping software. Differentially expressed genes were identified through fold change. Afterward, GO analysis and KEGG analysis were performed to detect the roles of these differential mRNAs.

\section{Real-time polymerase chain reaction}

RNA was reverse transcribed into cDNA according to kit instruction of cDNA kit-Applied Biosystems (Catalog \# 4374967) and purchased from Shanghi Sangon Biological Engineering Technology and Services Co., Ltd., which was then subjected to PCR amplification in the ABI Prism 7500 System (Applied Biosystems). Briefly, $1.5 \mu \mathrm{g}$ of total RNA from each sample was added to a mixture of $2.0 \mu \mathrm{l}$ of $10 \times$ reverse transcriptase buffer, $0.8 \mu \mathrm{l}$ of $25 \times \mathrm{dNTP}$ mix $(100 \mathrm{mM}), 2.0 \mu \mathrm{l}$ of $10 \times$ reverse transcriptase random primers, $1.0 \mu \mathrm{l}$ of multi-scribe reverse transcriptase, and $3.2 \mu \mathrm{l}$ of nuclease-free water. The final reaction mixture was held at $25^{\circ} \mathrm{C}$ for $10 \mathrm{~min}$, then heated to $37^{\circ} \mathrm{C}$ for $120 \mathrm{~min}$ and $85^{\circ} \mathrm{C}$ for $5 \mathrm{~s}$, and, finally, cooled to $4{ }^{\circ} \mathrm{C}$.

Quantitative analysis of target gene mRNA expression was performed via RT-PCR by subjecting the cDNA obtained from the above preparation methods to PCR amplification in 96-well optical reaction plates using the ABI Prism 7500 System (Applied Bio systems). The 25$\mu \mathrm{l}$ reaction mixture contained $0.1 \mu \mathrm{l}$ of $10 \mu \mathrm{M}$ forward primers and $0.1 \mu \mathrm{l}$ of $10 \mu \mathrm{M}$ reverse primers $(40 \mu \mathrm{M}$ final concentration of each primer), $12.5 \mu \mathrm{l}$ of SYBR Green Universal Mastermix, $11.05 \mu \mathrm{l}$ of nuclease-free water, and $1.25 \mu \mathrm{l}$ of the cDNA sample. The primers used in these assays were designed from PubMed (https://www. ncbi.nlm.nih.gov/tools/primer-blast/index.cgi?LINK_ LOC=BlastHome) and other databases and then were synthesized by Shanghi Sangon Biological Engineering Technology and Services Co., Ltd. which are listed in Table 1. Assay controls were incorporated into the same plate, which consisted of no template controls to test for contaminations of any of the assay reagents. The realtime PCR data were analyzed using the relative gene expression (i.e., $\Delta \Delta \mathrm{CT}$ ) method, as described in Applied Biosystems User Bulletin No. 2. Briefly, the data are presented as the fold change in gene expression normalized to an endogenous reference gene $(\mathrm{GAPDH})$ and relative to a calibrator.

\section{Statistical analysis}

Each value indicates the mean \pm SE of 100 preantral follicles per group. Statistical analysis was performed using one-way ANOVA followed by the Tukey-Kramer posttest (SPSS program version 17). 
Table 1 Primer sequences

\begin{tabular}{|c|c|c|c|c|}
\hline Gene symbol & Accession No. & Primer sequence $\left(5^{\prime}->3^{\prime}\right)$ & Product size & Annealing \\
\hline$\overline{\text { GAPDH }}$ & NM_001034034.2 & $\begin{array}{l}\text { F: GAGCTTGACAAAGTGGTCGTTGAG } \\
\text { R: CCAACGTGTCTGTTGTGGATCTGA }\end{array}$ & 218 & 55 \\
\hline FASTKD1 & NM_001102031.1 & $\begin{array}{l}\text { F: GGTACAGAGTTCGGAGGCTT } \\
\text { R: AGTGCACATCCCACTTGCTT }\end{array}$ & 386 & 55 \\
\hline BAG2 & NM_001034264.1 & $\begin{array}{l}\text { F; AACCGTCTGATGGGACGAAC } \\
\text { R: CTGTGTGGCTGCTTTAGGGA }\end{array}$ & 779 & 55 \\
\hline $\mathrm{RHOB}$ & NM_001077922.1 & $\begin{array}{l}\text { F: GCCAACAAGAAAGACCTGCG } \\
\text { R: ATAACACCCCATCCTCCCCA }\end{array}$ & 763 & 55 \\
\hline AGTR2 & XM_024988817.1 & $\begin{array}{l}\text { F: ACTCGAACAACGAAAGGTGT } \\
\text { R: AGCTGTTGGTGAATCCCAGG }\end{array}$ & 983 & 55 \\
\hline TM2D1 & NM_001079593.2 & $\begin{array}{l}\text { F: CGATTGCTCCCGATACTGCT } \\
\text { R: TCAAGGAGGCCCAAATCTGT }\end{array}$ & 629 & 55 \\
\hline MEF2A & NM_001083638.2 & $\begin{array}{l}\text { F: ACAGCCCAGACCCTGATACT } \\
\text { R: AGCATTCCTGGCGAGTTGAA }\end{array}$ & 763 & 55 \\
\hline BCL10 & NM_001078028.1 & $\begin{array}{l}\text { F: AGCCTITCCTGATGGAGCC } \\
\text { R: ACAGCACGTGATCGTAAGGG }\end{array}$ & 313 & 55 \\
\hline G2E3 & NM_001038671.2 & $\begin{array}{l}\text { F: AGACACGACTGAGAAGCTAATAC } \\
\text { R: TCTTCGGACGTCACAATGCT }\end{array}$ & 754 & 55 \\
\hline PRDX3 & NM_174432.2 & $\begin{array}{l}\text { F: TCCTCTACGTCTCTGTCGGG } \\
\text { R: TGCTTGATCGGAACCAGACC }\end{array}$ & 198 & 55 \\
\hline TRIAP1 & NM_001079776.1 & $\begin{array}{l}\text { F: GCCTGACCTTGAGCCATTCT } \\
\text { R: TGTTGTGCTGGGAACCCTTT }\end{array}$ & 131 & 55 \\
\hline IGF-I & NM_001077828.1 & $\begin{array}{l}\text { F: TGTGATTTCTTGAAGCAGGTGAAG } \\
\text { R: TTCATTGGGGGAAATGCCCA }\end{array}$ & 556 & 55 \\
\hline IGFBP3 & NM_174556.1 & $\begin{array}{l}\text { F: AGCGCAGCAGCTATTCCAA } \\
\text { R: TGCTGTGGTCTTCTTCCGAC }\end{array}$ & 565 & 55 \\
\hline
\end{tabular}

\section{Results}

Based on the staining results, we found that the ratio of healthy preantral follicles in cattle was higher $(26.7 \%$ and $20 \%$ ) than buffalo (10\% and $10 \%)$ in vivo and in vitro experiments, respectively (Table 2 ), which may explain why the yield of buffalo oocytes is lower than cattle oocytes per one ovary. After normalizing the microarray data for cattle preantral follicles, eleven genes were detected in cattle follicles (five upregulated and six downregulated) in large size compared to small size follicles. However, in buffalo follicles, 171 genes were detected (92 upregulated and 79 downregulated) in large size compared to small size follicles. Fold changes of the selected genes in cattle and buffalo were summarized in Table 3. The small and large sizes of bovine and buffalo preantral follicles were shown in Fig. 1.

\section{Gene expression results}

To confirm the data from microarray, we selected only 12 genes to assess their mRNA expression in two types (small and large) of preantral follicles: four genes (FASTKD1, IGF-I, RHOB, and AGTR2) in cattle only, two genes (BAG2 and TM2D1) in both cattle and buffalo, and six genes (MEF2C, BCL10, G2E3, IGFBP3, PRDX3, and TRIAP1) in buffalo only. We found that FASTKD1 and BAG2 were significantly downregulated in large size $(200-220 \mu \mathrm{m})$ cattle preantral follicles when compared to the small size $(100-120 \mu \mathrm{m})$, while RHOB, AGTR2, IGF-I, and TM2D1 were significantly upregulated (Fig. 2A). In buffalo, we found that transcript levels of BAG2, MEF2C, BCL10, IGFBP3, and G2E3 were significantly downregulated in large size when compared to small size follicles but both PRDX3 and TRIAP1 mRNA

Table 2 The percentage of viability of preantral follicles

\begin{tabular}{|c|c|c|c|c|c|c|c|}
\hline & \multirow{2}{*}{$\begin{array}{l}\text { No. of } \\
\text { isolated } \\
\text { preantral } \\
\text { follicles }\end{array}$} & \multicolumn{3}{|c|}{ Buffalo } & \multicolumn{3}{|l|}{ Cattle } \\
\hline & & Dead & Damage & Live (healthy) & Dead & Damage & Live (healthy) \\
\hline In vivo isolated preantral follicles & 3000 & $\begin{array}{l}1200 \\
(40 \%)\end{array}$ & $\begin{array}{l}1500 \\
(50 \%)\end{array}$ & $\begin{array}{l}300 \\
(10 \%)\end{array}$ & $\begin{array}{l}1000 \\
(33.3 \%)\end{array}$ & $\begin{array}{l}1200 \\
(40 \%)\end{array}$ & $\begin{array}{l}800 \\
(26.7 \%)\end{array}$ \\
\hline In vitro isolated preantral follicles & 1000 & $\begin{array}{l}500 \\
(50 \%)\end{array}$ & $\begin{array}{l}400 \\
(40 \%)\end{array}$ & $\begin{array}{l}100 \\
(10 \%)\end{array}$ & $\begin{array}{l}400 \\
(40 \%)\end{array}$ & $\begin{array}{l}400 \\
(40 \%)\end{array}$ & $\begin{array}{l}200 \\
(20 \%)\end{array}$ \\
\hline
\end{tabular}


Table 3 Microarray data show description and fold changes for some genes of study

\begin{tabular}{|c|c|c|c|c|c|c|c|c|}
\hline Probe set & $\begin{array}{l}\text { Gene } \\
\text { symbol }\end{array}$ & Gene description & Gene bank & $\begin{array}{l}\text { Gene } \\
\text { loc. }\end{array}$ & $\begin{array}{l}P \\
\text { value }\end{array}$ & $\begin{array}{l}\text { Large } \\
\text { size }\end{array}$ & $\begin{array}{l}\text { Small } \\
\text { size }\end{array}$ & $\begin{array}{l}\text { Fold } \\
\text { change }\end{array}$ \\
\hline \multicolumn{9}{|l|}{ Cattle } \\
\hline $\begin{array}{l}\text { Bt.8382.1.S1_- } \\
\text { at }\end{array}$ & $\mathrm{RHOB}$ & Ras homolog gene family, member B & $\begin{array}{l}\mathrm{NM}_{-} \\
001077922\end{array}$ & Ch.11 & 0.023 & 7.09 & 6.06 & +1.03 \\
\hline $\begin{array}{l}\text { Bt.27353.1.A1_- } \\
\text { at }\end{array}$ & AGTR2 & Angiotensin II receptor, type 2 & $\begin{array}{l}X M_{-} \\
001249373 \\
X_{-} \\
002699453\end{array}$ & Ch.X & 0.037 & 4.1 & 3.09 & +1.02 \\
\hline $\begin{array}{l}\text { Bt.26582.2.S1_ } \\
\text { at }\end{array}$ & TM2D1 & TM2 domain containing 1 & $\begin{array}{l}N_{-} \\
001079593\end{array}$ & Ch.3 & 7.32 & 6.09 & 4.7 & +1.3 \\
\hline $\begin{array}{l}\text { Bt.27103.1.A1_- } \\
\text { at }\end{array}$ & FASTKD1 & FAST kinase domains 1 & $\begin{array}{l}\mathrm{NM}_{-} \\
001102031\end{array}$ & Ch.2 & 0.39 & 3.75 & 5.07 & -1.32 \\
\hline $\begin{array}{l}\text { Bt.10885.2.S1_ } \\
\text { at }\end{array}$ & BAG2 & BCL2-associated athanogene 2 & $\begin{array}{l}\mathrm{NM}_{-} \\
001034264\end{array}$ & Ch.23 & 0.003 & 6.76 & 7.83 & -1.06 \\
\hline $\begin{array}{l}\text { Bt.12750.1.S1_- } \\
\text { at }\end{array}$ & IGF1 & Insulin-like growth factor 1 & $\begin{array}{l}\mathrm{NM}_{-} \\
001077828\end{array}$ & Ch5 & 0.046 & 5.39 & 4.3 & +1.08 \\
\hline \multicolumn{9}{|l|}{ Buffalo } \\
\hline $\begin{array}{l}\text { Bt.26582.2.S1_- } \\
\text { at }\end{array}$ & TM2D1 & TM2 domain containing 1 & $\begin{array}{l}\mathrm{NM}_{-} \\
001079593\end{array}$ & Ch.3 & 7.3 & 5.6 & 3.9 & +1.68 \\
\hline $\begin{array}{l}\text { Bt.5092.1.S1_ } \\
\text { at }\end{array}$ & PRDX3 & $\begin{array}{l}\text { Methylthioadenosine phosphorylase } \\
\text { peroxiredoxin } 3\end{array}$ & $\begin{array}{l}\text { NM_174432 } \\
\text { XM_ } \\
001251562 \\
\text { XM_ } \\
002689506\end{array}$ & Ch.24 & 2.4 & 10.75 & 7.73 & +3.02 \\
\hline $\begin{array}{l}\text { Bt.25343.1.S1_ } \\
\text { at }\end{array}$ & TRIAP1 & TP53 regulated inhibitor of apoptosis 1 & $\begin{array}{l}\mathrm{NM}_{-} \\
001079776\end{array}$ & Ch.17 & 2.4 & 10.16 & 8.79 & +1.36 \\
\hline $\begin{array}{l}\text { Bt.10885.2.S1_ } \\
\text { at }\end{array}$ & BAG2 & BCL2-associated athanogene 2 & $\begin{array}{l}N_{-} \\
001034264\end{array}$ & Ch.23 & 0.003 & 7.36 & 9.44 & -2.07 \\
\hline $\begin{array}{l}\text { Bt.16150.1.A1_ } \\
\text { at }\end{array}$ & MEF2C & Myocyte enhancer factor $2 \mathrm{C}$ & $\begin{array}{l}\mathrm{NM}_{-} \\
001046113\end{array}$ & Ch.7 & 0.08 & 6.04 & 7.6 & -1.6 \\
\hline $\begin{array}{l}\text { Bt.19656.2.A1_ } \\
\text { at }\end{array}$ & BCL10 & B cell CLL/lymphoma 10 & $\begin{array}{l}\mathrm{NM}_{-} \\
001078028\end{array}$ & Ch.3 & 0.056 & 4.7 & 5.7 & -1.08 \\
\hline $\begin{array}{l}\text { Bt.22493.1.S1_ } \\
\text { at }\end{array}$ & G2E3 & $\begin{array}{l}\text { G2/M-phase specific E3 ubiquitin protein } \\
\text { ligase }\end{array}$ & $\begin{array}{l}\mathrm{NM}_{-} \\
001038671\end{array}$ & Ch.21 & 0.003 & 4.7 & 5.9 & -1.19 \\
\hline Bt.422.1.S1_at & IGFBP3 & Insulin-like growth factor binding protein 3 & NM_174556 & Ch4 & 2.4 & 7.6 & 9.8 & -2.18 \\
\hline
\end{tabular}

expression were significantly upregulated in large size when compared to small sizes (Fig. 2B).

\section{Discussion}

Buffalo and cattle are an important livestock resource playing a crucial role in the agriculture economy of several countries of the Mediterranean regions including Egypt and East Asia like China. Complete list of flucogenesis and oogenesis and their roles in bovine's fertility are not known. Little is known about the molecular changes associated with the development of small to mature follicles. In many organisms, apoptosis is a normal part of development. Apoptosis is a well-thought-out vital component of several processes including change in gene expression, cell turnover, and the embryonic development. Owing to the complexities in the isolation of preantral follicles, the nature of these cell's death remains vaguely understood [5].

The apoptosis rate of the granulosa cells tends to increase during follicular development. Apoptosis is an ongoing process in ovarian preantral follicles and is most likely related to atresia [15]. We have focused our study on the assessment of expression of apoptosis-related genes in two stages of buffalo and cattle preantral follicle development, namely small and large preantral follicles which directly lead to follicular maturation. In cattle, we detected variances in an expression of only 11 apoptosisrelated genes by microarray analysis, six downregulated (FASTKD1, BAG2, PTCH1, DBH, SHH, PTK2), and five upregulated transcripts in large follicles (LCK, RHOB, 


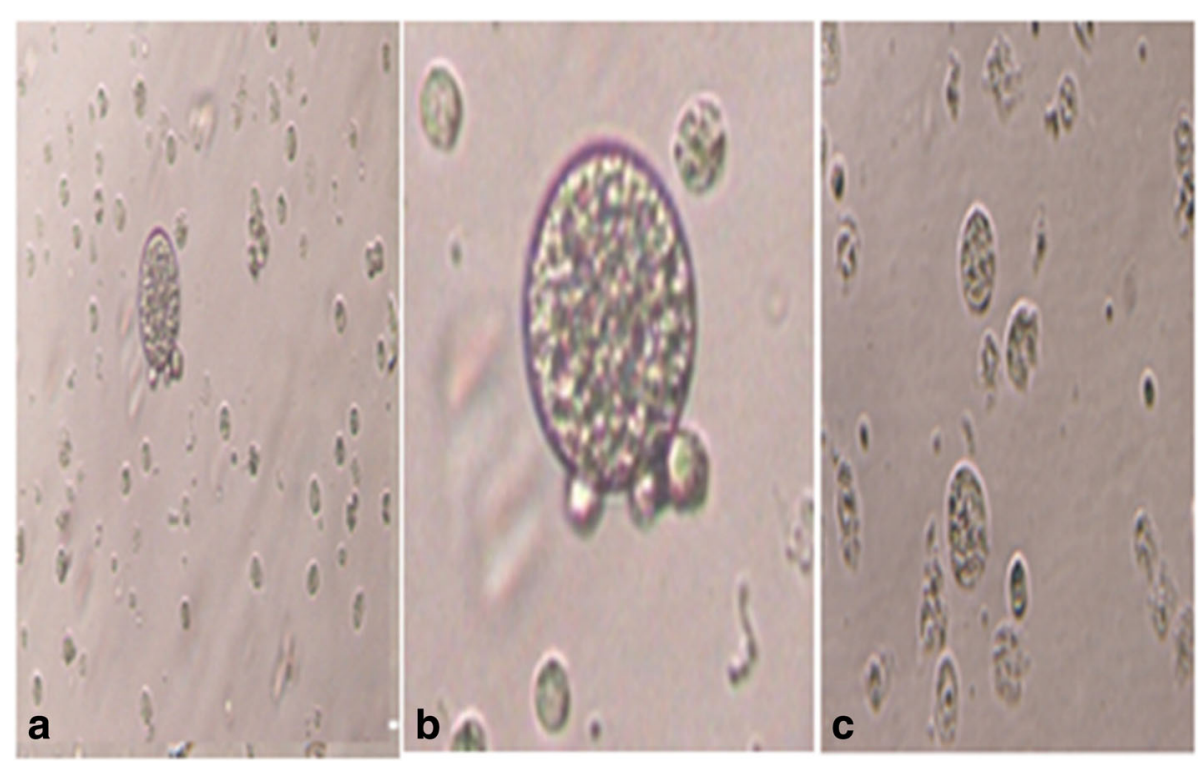

Fig. 1 Showing different sizes of bovine and buffalo preantral follicles. $\mathbf{a}$ and $\mathbf{b}$ represent healthy preantral follicles and $\mathbf{c}$ represent non-healthy (degenerated) preantral follicles

AGTR2, TM2D1, IGF1) when compared to small preantral follicles, while in buffalo, we found variances in an expression of 171 apoptosis-related genes, 92 upregulated, and 79 downregulated transcripts in large preantral follicles when compared to small preantral follicles size.

FASTKD1 was shown to protect cells from oxidative stress-induced cell death and to suppress autophagy, whereas downregulation of FASTKD1 sensitized cells to cell death mechanisms [16]. Bcl-2-associated athanogene (BAG) family proteins interact with various partners included in modifying the proliferation/death balance, including the anti-apoptotic Bcl-2, and enhance its antiapoptotic effects [17]. Our results were in agreement with Yang et al. [18] as we have detected significant differences between large and small follicles in both cattle and buffalo. IGFs are considered one of the inhibitor cytokines for apoptosis and play a vital role in regulating cellular homeostasis [19]. Healthy follicles had levels of IGF-I significantly higher than slightly atretic and atretic follicles [20]. Also, Ginther et al. [21] provide that the level of IGF-I increased in the largest follicles of bovine. Besides, IGFs had been correlated with changes in negative and positive regulators of the Bcl-2 family and alteration of Bax and Bcl2 levels [22]. The present results of microarray and RT-PCR show that IGF-I was upregulated in large preantral follicles of cattle compared with small size follicles while IGFBP3 was downregulated in large preantral follicles of buffalo.

MEF2C acts as an anti-apoptotic factor and keeps the transplanted cells alive after differentiation in embryonic stem cells [23]. Our microarray and qPCR data detected changes in the mRNA level in large preantral follicles when compared to the small preantral follicles. AGTR2 is transcribed from an X-linked gene and enters in several signaling cascades influencing neuronal differentiation, cell proliferation, growth inhibition, and induction of apoptosis [24]. G2E3 gene plays an effective role in early embryonic development. Also, it acts as a regulator for cell death because it causes cellular apoptosis when reduced [12]. PRDX3 gene is in the control of cell proliferation and apoptosis as was cited by Rhee and Woo [25]. Downregulation of PRDX3 enhances cisplatininduced ovarian cancer cell apoptosis [26]. TR1AP1 alters the transcriptional activity of the genes correlated to cell death, so it was looked upon as initiating apoptosis [27].

The present study showed that the viability of preantral follicles in cattle was higher than buffalo, and damaged or dead preantral follicles in buffalo were higher than cattle. The intrinsic species-specific lower number of primordial and antral follicles in buffalo compared to cattle were investigated which underlines the difficulty of the great variability in follicular recruitment in this animal $[28,29]$. It has been reported that buffalo has a smaller number of primordial follicles than bovine species, smaller antral follicles, and a higher incidence of atresia [30]. It is possible to think that animals with low follicle count such as buffalo have lower fertility than cattle [31], and this change in fertility between these two species is related to changes in the transcriptome.

On the other hand, the present results of RT-PCR showed that Rhob, TM2D1, and IGFI which are considering as anti-apoptotic genes were upregulated in large 

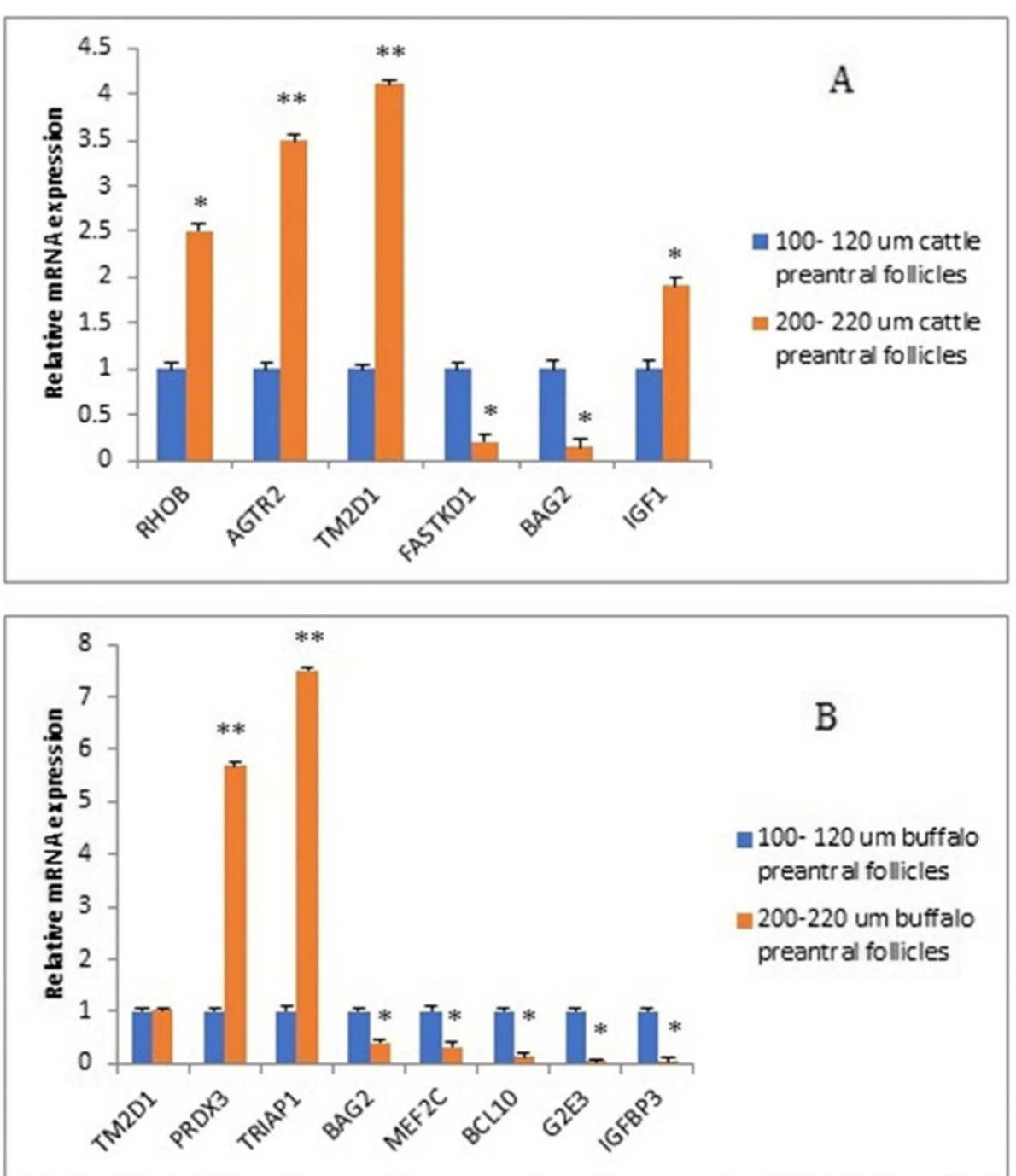

Fig. 2 The expression values of apoptotic genes in preantral follicles for large and small size in both buffalo and cattle

cattle preantral follicle while applied anti-apoptotic genes (TM2D1, G2E3, MEF2, and IGFBP3) were downregulated in large buffalo preantral follicle.

Although we found out that many genes were either down- or upregulated more in buffalo preantral follicles than in cattle leading to increasing apoptosis and supporting our previous suggestion, we found other few genes for which anti-apoptotic genes were upregulated more in buffalo than in cattle. These results conflicted with a lot of genes which supported the hypothesis that apoptosis were more in buffalo follicles than in cattle. The presence of several genes opposing this content was clear and explicit.

FASTKD1, for example, which is considered as antiapoptotic gene (antiapoptotic, prosurvival), was significantly downregulated in large cattle preantral follicles. RHOB (pro-apoptotic) gene also increased only in large cattle preantral follicles when compared to small preantral follicles This conflict in transcriptome related to the apoptotic process opened the door for new studies to focus on the dynamics of these genes working within a single cell by using single cell-RNA sequencing.

\section{Conclusion}

The mechanism of buffalo follicular development is different from that of cattle, which is the main reason for the lack of oestrus, irregular ovulation, and low conception rate in estrus. The staining results consent with microarray, and RT-PCR results showed that the percentage of healthy cattle preantral follicles was more than buffalo. Microarray results showed that many genes related to apoptosis in buffalo (171 genes) were more than cattle (11 genes). RT-PCR data indicated that most of the apoptosis genes were upregulated in large preantral follicles, and anti-apoptosis genes were downregulated in buffalo. In contrast, the apoptotic genes were 
downregulated in large preantral follicles, and antiapoptosis genes were upregulated in cattle which mean that preantral follicles with successful maturation contain anti-apoptosis genes or downregulated apoptotic genes. Also, these new data for transcriptome may open a new window for confirmation that cattles are more fecund than buffalo.

\section{Acknowledgements}

Not applicable

\section{Authors' contributions}

All authors participated in the design, interpretation of the studies and analysis of the data and review of the manuscript; KZ designed this study. $Y L, A A, H A$, and $A E$ participated in the conduct of the study. $A A, Y L, A E$, and $K Z$ conducted the experiments; $K Z$ supplied critical reagents; and $K Z$ and $A A$ wrote the manuscript. All authors have read and approved the manuscript

\section{Funding}

This study was funded by National Key Technology R and D Project of China No.2006BAD04A02) Huazhong Agricultural University, Wuhan, China and National Research Centre, Dokki, Egypt. Most chemicals and kits were purchased by project No. 2006BAD04A02.

\section{Availability of data and materials}

Data is available for all.

\section{Declarations}

\section{Ethics approval and consent to participate}

The experimental protocol used in the study was approved (NRCE-CBD1032019) by the Animal Care and Use Committee of National Research Centre, Egypt. The laboratory experiments and protocols were handled in accordance with the guidelines described by Department of Basic Medical Sciences, Kulliyyah (College) of Medicine, International Islamic University Malaysia.

\section{Consent for publication}

Not applicable in this section.

\section{Competing interests}

The authors declare that they have no competing interests.

\section{Author details}

${ }^{1}$ Cell Biology Department, National Research Centre, Dokki 12622, Egypt. ${ }^{2}$ Key Laboratory of Agricultural Animal Genetics, Breeding and Reproduction of Ministry of Education, College of Animal Science and Technology, Huazhong Agricultural University, Wuhan, People's Republic of China. ${ }^{3}$ Department of Basic Medical Sciences, Kulliyyah of Medicine, International Islamic University Malaysia, 25200 Kuantan, Pahang Darul Makmur, Malaysia.

Received: 13 May 2021 Accepted: 25 September 2021

Published online: 08 October 2021

\section{References}

1. Palta PCM (1998) Laboratory production of buffalo (Bubalus bubalis) embryos. Reprod Fert Devel 10(5):379-391. https://doi.org/10.1071/RD98085

2. Ireland JLH, Scheetz D, Jimenez-Krassel F, Themmen APN, Ward F, Lonergan P, Smith GW, Perez GI, Evans ACO, Ireland JJ (2008) Antral follicle count reliably predicts number of morphologically healthy oocytes and follicles in ovaries of young adult cattle. Biol Reprod 79(6):1219-1225. https://doi.org/1 0.1095/biolreprod.108.071670

3. Erickson B (1966) Development and senescence of the postnatal bovine ovary. J Anim Sci 25(3):800-805. https://doi.org/10.2527/jas1966.253800x

4. Zhou J, Peng X, Mei S (2019) Autophagy in ovarian follicular development and atresia. Int J Biol Sci 15(4):726-737. https://doi.org/10.7150/ijbs.30369 Available from https://www.ijbs.com/v15p0726.htm

5. Elmore S (2007) Apoptosis: a review of programmed cell death. Toxicol Pathol 35(4):495-516. https://doi.org/10.1080/01926230701320337
6. Singh N, Bose K (2015) Apoptosis: Pathways, Molecules and Beyond. In: Bose K. (eds) Proteases in apoptosis: pathways, protocols and translational advances. Springer, Cham. https://doi.org/10.1007/978-3-319-19497-4_1

7. Martinou JC, Youle RJ (2011) Mitochondria in apoptosis: BCl-2 family members and mitochondrial dynamics. Dev Cell 21(1):92-101. https://doi. org/10.1016/j.devcel.2011.06.017

8. Amaral JD, Xavier JM, Steer CJ, Rodrigues CM (2010) The role of p53 in apoptosis. Discov Med 9(45):145-152. PMID: 20193641

9. Zhang M, Zheng J, Nussinov R (2017) Buyong M. Release of cytochrome C from bax pores at the mitochondrial membrane. Sci Rep 7(1):2635. https:// doi.org/10.1038/s41598-017-02825-7

10. Mcllwain DR, Berger T, Mak TW (2013) Caspase functions in cell death and disease. Cold Spring Harbor Perspect In Biol 5(4):a008656. https://doi.org/1 $0.1101 /$ cshperspect.a008656

11. Jourdain AA, Johannes P, Miguel AF, Jean-Claude M, Paul A, Maria S (2017) The FASTK family of proteins: emerging regulators of mitochondrial RNA biology. Nucleic Acids Res 19(19):10941-10947. https://doi.org/10.1093/nar/gkx772

12. Brooks WS, Banerjee S, Crawford DF (2014) RNF138/NARF is a cell cycle regulated E3 ligase that poly-ubiquitinates G2E3. JSM Cell Dev Biol 2(1):1005

13. Laura AM, llah B, Robert CS, John AC, Marlow LA, Bok I, Smallridge RC, Copland JA (2015) RhoB upregulation leads to either apoptosis or cytostasis through differential target selection. Endocr Relat Cancer 5(3):777-792. https://doi.org/10.1016/s0378-4320(96)01588-6

14. Khairy MAZ, Nermin E, Xiang L, Moaeen-ud D, Li-Guo Y (2008) Long-Term in vitro Culture of Bovine preantral follicles by using different culture media. J Biol Sci 8(2):386-391. https://doi.org/10.3923/jbs..386.391

15. Liu ZH, Yue KZ, Ma SF, Sun XS, Tan JH (2003) Effects of pregnant mare serum gonadotropin (eCG) on follicle development and granulosa-cell apoptosis in the pig. Theriogenology 59(3-4):775-785. https://doi.org/10.101 6/s0093-691x(02)01122-6

16. Marshall KD, Klutho PJ, Song L, Krenz M, Baines CP (2019) The Novel Cyclophilin-D Interacting Protein FASTKD1 Protects Cells Against Oxidative Stress-Induced Death. Am J Physiol Cell Physiol 317(3):C584-C599. https:// doi.org/10.1152/ajpcell.00471.2018

17. Wang HQ, Zhang HY, Hao FJ, Meng X, Guan Y, Du ZX (2008) Induction of BAG2 protein during proteasome inhibitor-induced apoptosis in thyroid carcinoma cells. Br J Pharmacol 5(5):655-660. https://doi.org/10.1038/bjp.2 008.302

18. Yang KM, Bae E, Ahn SG, Pang K, Park Y, Park J, Lee J, Ooshima A, Park B, Kim J, Jung Y, Takahashi S, Jeong J, Park SH, Kim SJ. (2017) Co-chaperone BAG2 determines the pro-oncogenic role of cathepsin B in triple-negative breast cancer cells. Cell Reports 21(10):2952-2964. https://doi.org/10.1016/j. celrep.2017.11.026

19. Yin DL, Pu L, Pei G (1998) Antisense oligonucleotide to insulin-like growth factor II induces apoptosis in human ovarian cancer AO cell line. Cell Res 8(2):159-165. https://doi.org/10.1038/cr.1998.16

20. Yu YS, Sui HS, Han ZB, Li W, Luo MJ, Tan JH (2004) Apoptosis in granulosa cells during follicular atresia: relationship with steroids and insulin-like growth factors. Cell Res 14(4):341-346. https://doi.org/10.1038/sj.cr.7290234

21. Ginther OJ, Bergfelt DR, Beg MA, Kot K (2001) Effect of LH on circulating oestradiol and follicular fluid factor concentrations during follicle deviation in cattle. Reproduction 122(1):103-110. 11425334. https://doi.org/10.1530/ rep.0.1220103

22. Lei W, Weiqiong Ma, Rachelle M, Wen-Lieng L, Ping HW (1998) Insulin-Like Growth Factor I Modulates Induction of Apoptotic Signaling in $\mathrm{H} 9 \mathrm{C2}$ Cardiac Muscle Cells, Endocrinology 139(3):1354-1360. https://doi.org/10.121 0/endo.139.3.580

23. Zhen L, Scott RM, Jiankun C, Zhiguo N, Walid S, Amanda JR, Tina S, Shu-ichi O, Jeffrey HL et al (2008) Lipton1MEF2C as a neurogenic and anti-apoptotic transcription factor in murine embryonic stem cells. J Neurosci 28(26):65576568. https://doi.org/10.1523/JNEUROSCI.0134-08.2008

24. Gendron L, Payet MD, Gallo-Payet N (2003) The angiotensin type 2 receptor of angiotensin II and neuronal differentiation: from observations to mechanisms. J Mol Endocrinol 31(3):359-372. https://doi.org/10.1677/jme.0. 0310359

25. Rhee SG, Woo HA (2011) Multiple functions of peroxiredoxins: peroxidases, sensors and regulators of the intracellular messenger $\mathrm{H} 2 \mathrm{O} 2$, and protein chaperones. Antioxid Redox Signal 15(3):781-794. https://doi.org/10.1089/a rs.2010.3393

26. Jie D, Yan L, Chengwen S, Jun X, Yan W, Yang Y (2013) siRNA targeting of PRDX3 enhances cisplatin-induced apoptosis in ovarian cancer cells through 
the suppression of the NF-KB signaling pathway. Mole Medi Rep 7(5):16881694. https://doi.org/10.3892/mmr.2013.1370

27. Fook-Alves VL, de Oliveira MB, Zanatta DB, Strauss BE, Colleoni GW (2016) TP53 Regulated Inhibitor of Apoptosis 1 (TRIAP1) stable silencing increases late apoptosis by up-regulation of caspase 9 and APAF1 in RPMI8226 multiple myeloma cell line. Biochim Biophys Acta 1862(6):1105-1110. https://doi.org/10.1016/j.bbadis.2016.03.011

28. Disha S, Parkash B, Dhindsa SS, Mrigank H (2017) Ovarian follicular dynamics during estrous cycle in dairy buffalo. Indian Vet J 94(02):69-71

29. Santos SSD, Ferreira MAP, Lima MYS, Sampaio RV, Cordeiro MS, Silva TVG et al (2011) Quantification, morphology and ultrastructure of preantral follicles of buffalo (Bubalus bubalis) Foetuses. Reprod Domest Anim 46:1722

30. Kumar A, Solanki VS, Jindal SK, Tripathi VN (1997) Oocyte retrieval and histological studies of follicular population in buffalo ovaries. Anim Reprod Sci 47(3):189-195. https://doi.org/10.1016/S0378-4320(96)01588-6

31. Jesus $A B$, Jose JE, Ariel MT, Albeiro $L$ (2017) Differences of the Fertility Potential between Buffaloes (Bubalus bubalis) and Cattle (Bos indicus): The Role of Antimullerian Hormone (AMH). J Buff Sci 6:74-80. https://doi.org/10. 6000/1927-520X.2017.06.03.2

\section{Publisher's Note}

Springer Nature remains neutral with regard to jurisdictional claims in published maps and institutional affiliations.

\section{Submit your manuscript to a SpringerOpen ${ }^{\circ}$ journal and benefit from:}

- Convenient online submission

- Rigorous peer review

- Open access: articles freely available online

High visibility within the field

- Retaining the copyright to your article

Submit your next manuscript at $\boldsymbol{\nabla}$ springeropen.com 